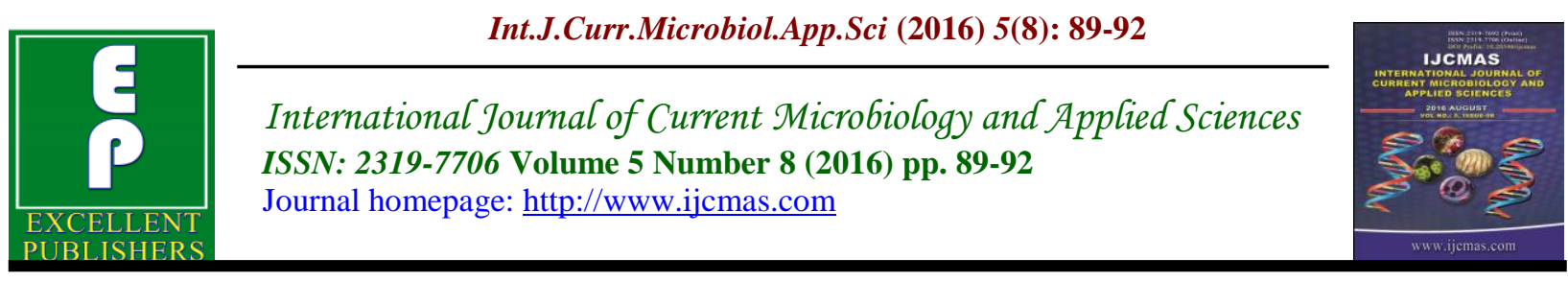

Review Article

http://dx.doi.org/10.20546/ijcmas.2016.508.011

\title{
Origin, Evolution and Milestones in the Field of Natural Product Research
}

\author{
Shivakanth Chintalapally* and D. Manohar Rao \\ Department of Genetics, Osmania University, India \\ *Corresponding author
}

\begin{tabular}{|c|c|}
\hline & A B S T R A C T \\
\hline $\begin{array}{l}\text { Traditional } \\
\text { medicine, } \\
\text { history of } \\
\text { medicinal } \\
\text { plants. }\end{array}$ & \multirow{3}{*}{$\begin{array}{l}\text { Natural products, specifically from plants have been the basis of curing } \\
\text { human diseases. The history of medicine is rooted in the existence of human } \\
\text { civilization. The present day medicine system has evolved over the years by } \\
\text { the enduring scientific and observational efforts of researchers; however, the } \\
\text { basis of its development remains rooted in traditional medicine. Plant-based } \\
\text { medicines which were used as crude drugs now serve as the basis of novel } \\
\text { drug discovery. The indigenous knowledge of herbal formulations were } \\
\text { passed down from generation to generation which has significantly } \\
\text { contributed to the development of different traditional systems of medicine. } \\
\text { The present review gives a brief account of the history of the documented } \\
\text { history of medicinal plants from various sources. }\end{array}$} \\
\hline Article Info & \\
\hline $\begin{array}{l}\text { Accepted: } \\
\text { 06 July } 2016 \\
\text { Available Online: } \\
\text { 12 August } 2016\end{array}$ & \\
\hline
\end{tabular}

\section{Introduction}

Ayurveda is an Indian medical system which includes diet and herbal remedies, apart from emphasizing the body, mind and spirit in prevention of disease and treatment (Morgan, 2002).

The documentation of the Indian Ayurveda system dates back to the 1st millennium BC (Bhushan Patwardhan et al., 2004).

Multidimensional therapeutic uses of plants in a traditional way were known in India since the Vedic times as Ayurvedic system of medicine. The Rig Veda (4500 and 1600 $\mathrm{BC}$ ) one of the oldest repository of human knowledge mentions the use of plants. "Susruta Samhita" (before 1000 BC) written in Sanskrit included a comprehensive chapter on therapeutics apart from surgery.

Charaka Samhita dedicates 5 chapters to dietetics ("Aharatattva"), stating that wholesome diet is essential for good health and to prevent diseases, while unwholesome food is an important cause of diseases (Priyadaranjan et al., 1980). "Charaka Samhita" gives a remarkable description of the materia medica in ancient India.

The Bower Manuscript (named after Hamilton Bower, a British Army intelligence officer) is an early birch bark document discovered near a ruined Buddhist monastery near Kuchar in Chinese Turkestan. One of the earliest health science anthologies "Nei Ching" dates back to 1300 BC (Nakanishi, 1999). "The Chinese 
Meteria Medica" was documented around 1100 BC (Cragg et al., 2001). "Pen-ts'as kang mu", a Chinese drug encyclopedia records 1898 herbal drugs and 8160 prescriptions, was compiled during the Ming Dynasty by Li Shih-Chen (1596 AD) (Glaser, 2008). The "Ebers Papyrus", an Egyptian script prescribes nearly 1000 substances and formulations, most of which are plant-based medicines.

"De Materia Medica" a Greek document was compiled by Pedanius Dioscorides(100 AD) which elaborated methods of the collection, storage and the medicinal uses of various plant species. Theophrastus (300 B.C.), the Greek natural scientist and a philosopher, mentioned about different uses of medicinal herbs. The ancient Mesopotamian civilization (2600 B.C.) has a documented description of natural products on clay tablets in cuneiform viz. extracted oils from Cypress (Cupressus sempervirens) and Myrrh (Commiphora species) which are still being used in Eygypt to treat coughs, colds and inflammation (Cragg et al., 2005). The Arabs were the first to privately own pharmacies (8th century). "Canon Medicinae" was medicinal document compiled by Avicenna, a Persian pharmacist (Cragg et al., 2000).

Due to the presence of a written knowledge and proven theoretical principles, the traditional medicinal systems such as Ayurveda and Chinese Medicine were constantly revised through centuries and enjoy the faith of people till today. On the other hand folklore medicine, shamanism and herbalism have no documented evidence and the medicinal formulations used are mostly kept secret by their practitioners (Brusotti et al., 2014). The Natural products (secondary metabolites) from plant origin have a proven track record of being the most successful sources of potential drug leads (Mishra et al., 2011).

In conclusion, a narrow turn from natural products to combinatorial chemistry during the early 1990s has created some lacuna in the development of new drugs from natural sources.

Fig.1 A documented page of Susrutha Samhita

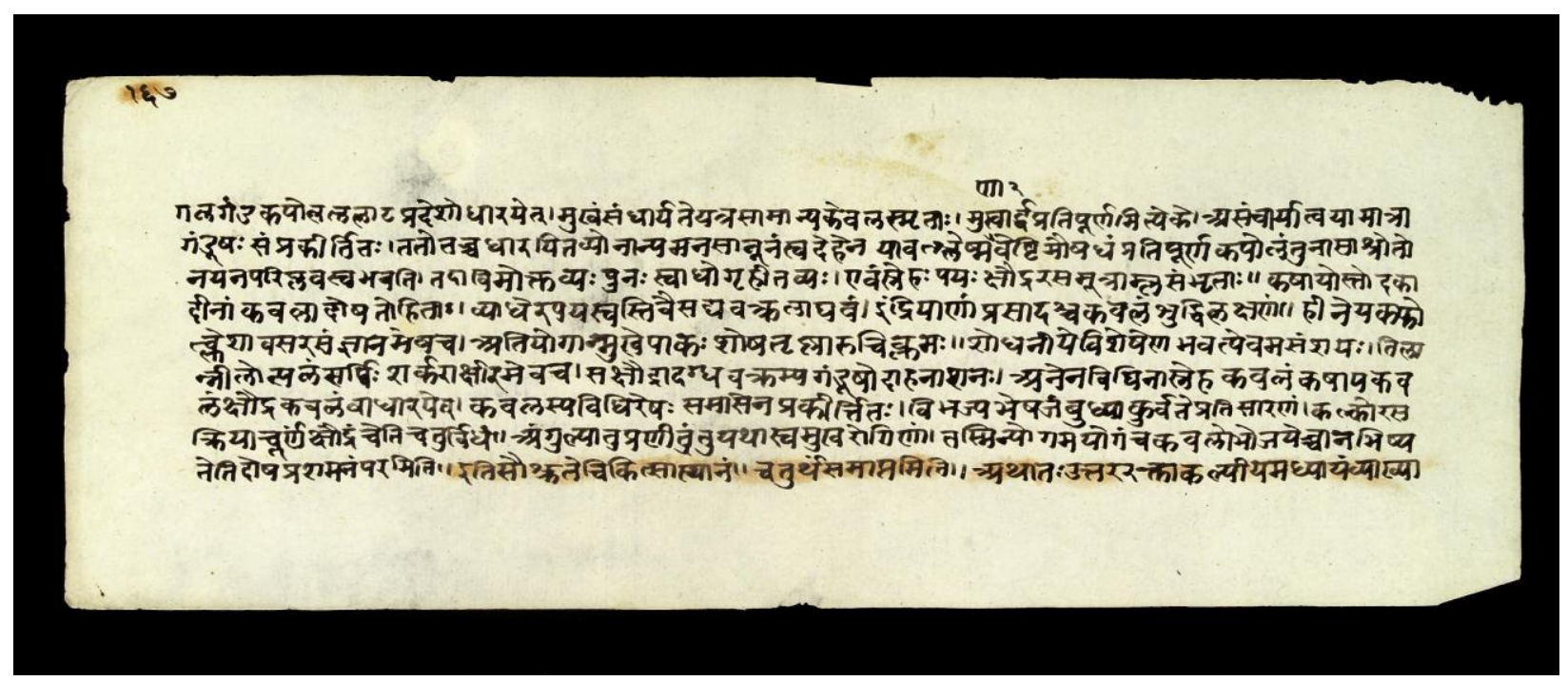


Fig.2 Sanskrit language manuscript (Bower Manscript) is written on Birch leaves in the Late Brahmi script, and contains some Prakrit.(11)

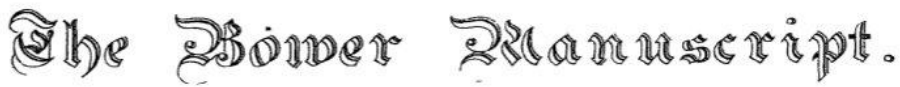

Part V1 Leaf 3

(s)bverse.

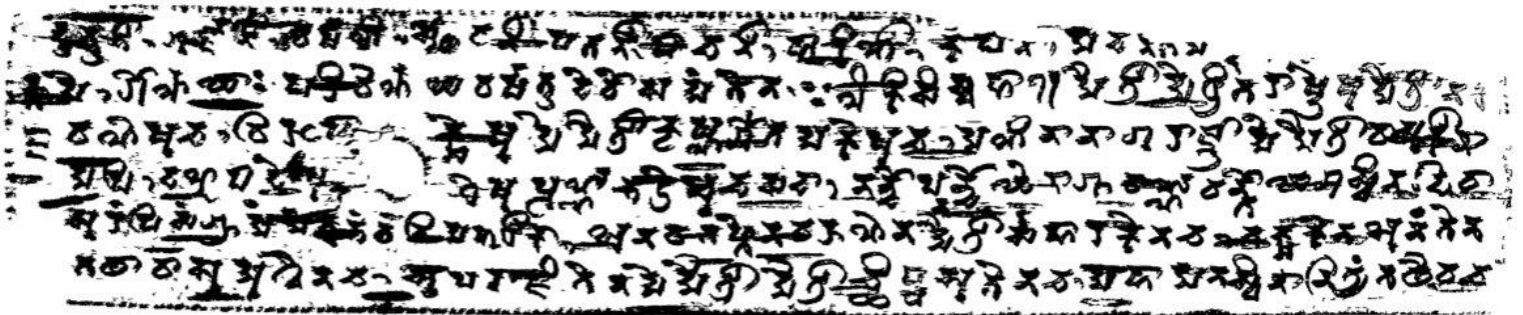

keverse.

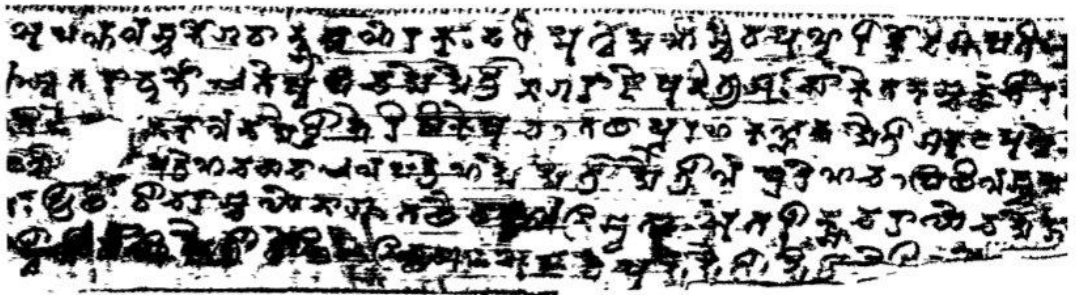

However, traditional knowledge represents a cumulative experience of thousands of years of therapeutic practice with exemplary trust of people. The recent scientific studies carried out by researchers also endorse the traditional medical system.

A continuous effort is needed to standardize and optimize the traditional herbs apart from identifying the active principle and continue to be competitive with other drug discovery methods. The world of plants, and indeed all natural sources, represent a virtually untapped reservoir of novel drugs awaiting imaginative and progressive organizations (Brahmachari, 2009).

\section{Acknowledgement}

I thank University Grants Commission
(UGC), New Delhi, India for granting me Research Fellowship in Science for Meritorious Students - GATE (RFSMSGATE) fellowship for carrying out me research. I thank the Department of Genetics, Osmania University for providing me with facilities. I thank my guide Prof. D. Manohar Rao who has been a great source of inspiration for me.

\section{References}

Bhushan Patwardhan, Ashok, D.B., Vaidya and Mukund Chorghade. 2004. Curr. Sci., Vol. 86, No. 6, 25.

Brahmachari, G. 2009. Mother nature - an inxahaustible source of drugs and lead molecules. In: Brahmachari G. (ed), Natural Products: Chemistry, Biochem. Pharmacol., pp. 1-20, 
Narosa Publishing House, New Delhi, India.

Brusotti, G., Cesari, I., Dentamaro, A., Caccialanza, G., Massolini, G. 2014. Isolation and characterization of bioactive compounds from plant resources: the role of analysis in the ethnopharmacological approach. $J$. Pharm. Biomed. Anal., 87: 218-228.

Cragg, G.M., Newman, D.J. 2001. Natural product drug discovery in the next millennium. Pharm. Biol., 39: 8-17.

Cragg, G.M., Newman, D.J. 2005. Biodiversity: A continuing source of novel drug leads. Pure Appl. Chem., 77: 7-24.

Glaser, V. 2008. An interview with David Newman. Assay Drug Develop. Technol., 6: 1-7.
Meulenbeld, G.J. (1999-2002). A History of Indian Medical Literature, vol. IIa, pp. 3-12.

Mishra, B.B., Tiwari, V.K. 2011. Natural products: An evolving role in future drug discovery. Eur. J. Med. Chem., 46: 4769-4807.

Morgan, K. 2002. Medicine of the Gods: Basic Principles of Ayurvedic Medicine (http://www. compulink.co. $\mathrm{uk} / \sim$ mandrake/ayurveda.htm)

Nakanishi, K. 1999. An historical perspective of natural products chemistry. In: Ushio S. (ed), Comprehensive Natural Products Chem., 1: p. 23, Elsevier Science BV, Amsterdam.

Priyadaranjan Ray, Hirendranath Gupta, 1980. History of Sciences in India Publications, Caraka Samhita - A Scientific Synopsis, pp. 18-19.

\section{How to cite this article:}

Shivakanth Chintalapally and D. Manohar Rao. 2016. Origin, Evolution and Milestones in the Field of Natural Product Research. 2016. Int.J.Curr.Microbiol.App.Sci. 5(8): 89-92. doi: http://dx.doi.org/10.20546/ijcmas.2016.508.011 